\title{
The Formation of The Tang Estate Poem
}

\section{Citation}

Owen, Stephen. 1995. The formation of the Tang estate poem. Harvard Journal of Asiatic Studies 55(1): 39-59.

\section{Published Version}

http://www.jstor.org/stable/i327740

\section{Permanent link}

http://nrs.harvard.edu/urn-3:HUL.InstRepos:2609647

\section{Terms of Use}

This article was downloaded from Harvard University's DASH repository, and is made available under the terms and conditions applicable to Other Posted Material, as set forth at http:// nrs.harvard.edu/urn-3:HUL.InstRepos:dash.current.terms-of-use\#LAA

\section{Share Your Story}

The Harvard community has made this article openly available.

Please share how this access benefits you. Submit a story.

Accessibility 


\section{Harvard-Yenching Institute}

The Formation of The Tang Estate Poem

Author(s): Stephen Owen

Source: Harvard Journal of Asiatic Studies, Vol. 55, No. 1 (Jun., 1995), pp. 39-59

Published by: Harvard-Yenching Institute

Stable URL: http://www.jstor.org/stable/2719420

Accessed: 12/02/2009 06:29

Your use of the JSTOR archive indicates your acceptance of JSTOR's Terms and Conditions of Use, available at http://www.jstor.org/page/info/about/policies/terms.jsp. JSTOR's Terms and Conditions of Use provides, in part, that unless you have obtained prior permission, you may not download an entire issue of a journal or multiple copies of articles, and you may use content in the JSTOR archive only for your personal, non-commercial use.

Please contact the publisher regarding any further use of this work. Publisher contact information may be obtained at http://www.jstor.org/action/showPublisher?publisherCode=hyi.

Each copy of any part of a JSTOR transmission must contain the same copyright notice that appears on the screen or printed page of such transmission.

JSTOR is a not-for-profit organization founded in 1995 to build trusted digital archives for scholarship. We work with the scholarly community to preserve their work and the materials they rely upon, and to build a common research platform that promotes the discovery and use of these resources. For more information about JSTOR, please contact support@jstor.org. 


\section{The Formation of the Tang Estate Poem}

\section{STEPHEN OWEN}

Harvard University

$\mathrm{T}$

' HE Tang estate poem, although not without precedents, first took on its characteristic features during the second reign of Zhongzong 中宗 (705-710), ${ }^{1}$ when notices of literary occasions increasingly made reference to estates as such (zhuang 莊, shu 墅, or bieye 別業). A new interest was taken in exurban nature, sometimes around Luoyang but primarily in the Chengnan 城南 region south of Chang'an, and with that interest came a set of values that was to linger on into later estate and garden poetry.

Such heightened interest was clearly related to the formation of vast Chengnan estates by the imperial princesses-Taiping 太平公主, Anle 安樂公主, and Changning 長寧公主-who, together with Empress Wei, dominated both the era and the emperor. The estates of the three princesses were all sites of imperial visits mentioned in the

1 What I am considering the "estate poem" overlaps with banquet and excursion poetry. It is not so much a true subgenre as a topic, involving the adaption of existing subgenres to the growing interest in private estates and exurban nature early in the eighth century. The estate poem is closely related to the rich corpus of poems on imperial excursions and their attendant banquets. It is also also in the lineage of poetry on open air banquets, such as the “Gathering for a Banquet at Ande's Mountain Pool”' (Ande shanchi yanji 安德山池宴集), from the first part of the seventh century. Wenyuan yinghua (Taibei: Xinwenfeng chuban gongsi, 1979) $165.5 b-7 a$. From later in the seventh century we have the private estate banquet of Gao Zhengchen Tangshi jishi (Taibei: Taiwan zhonghua shuju, 1970) 7. 86-93; see also Stephen Owen, Poetry of the Early T'ang (New Haven: Yale University Press, 1977), pp. 276-80. 
record of court occasions preserved in Tangshi jishi 唐詩紀事. ${ }^{2}$ Many of the poems on these occasions have been preserved in what seem to be the full original series in Wenyuan yinghua 文苑英華. ${ }^{3}$

The formal pomp of an imperial visit by Zhongzong to his daughter's or sister's estate yielded a poetry little different from that of other court excursions during the period. The interest in estates, however, went beyond the conventions of celebrating such court occasions. We also find poems on the more modest estates of lesser princesses and courtiers. Located on the margin between wild and domesticated Nature, the estate became a space of private withdrawal without the renunciation of public life. It is the literary construction of such a space, which went hand in hand with more tangible dredging and piling, that is my topic here.

On the fourth of June in the year 710, just two months before he died, probably poisoned by his wife, the emperor Zhongzong paid a visit to the estate of the Princess Changning, his daughter by Empress Wei. The estate had been built near Mount Zhongnan on the site of an abandoned guard camp, combined with land confiscated from one Gao Shilian. It was supposed to have had a three-storied mansion, with the local landscape improved by the usual laborintensive means. ${ }^{4}$ Several of the literary courtiers of the Xiuwen guan 修文館 (Bureau for the Enhancement of Letters) were in attendance and composed poems for the banquet. ${ }^{5}$ The following is the offering by the venerable Li Jiao 季嶠, one of the Grand Scholars 大 學士 of the Xiuwen guan ("In Attendance at a Banquet at Princess Changning's Eastern Villa: To Command"'; 03538): ${ }^{6}$

2 Tangshi jishi 9.113-15.

${ }^{3}$ It seems likely that the Wenyuan yinghua editors had access to an old collection of the poems on these occasions, which was copied into Wenyuan yinhua.

${ }^{4}$ Xin Tang shu (Beijing: Zhonghua shuju, 1975) 83.3653.

5 Wenyuan yinghua $176.7 \mathrm{~b}-8 \mathrm{a}$. The Xiuwen guan was a literary bureau founded in 708 by Shanguan Wan'er: see Zhang Yue 張説, Tang Zhaorong Shangguan shi wenji xu 唐昭容上官氏 文集序, Quan Tang wen (Beijing: Zhonghua shuju, 1983) 225.18a.

${ }^{6}$ The five-digit numbers refer to poems in Hiraoka Takeo 平岡武夫 et al., Tödai no shihen 唐代の詩編, Tang civilization reference series, 11-12, Institute for Humanistic Studies, Jimbun (Kyoto: 1964-64). This poem is given in an even earlier source, the Chuxue ji 初學記 (Beijing: Zhonghua shuju, 1962) 10.246. I have followed Chuxue $j i$ and Wenyuan yinghua in reading 敂 rather than 鑾 of Quan Tang shi, though there is little reason to prefer either of these closely related words; these may well be luan, "carriage bells." Both Chuxue ji and Wenyuan yinghua read 㬎 rather than 宛鳥, the Quan Tang shi reading. Although the compound is sometimes writ- 


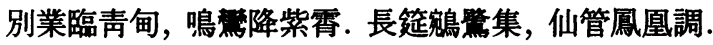

樹接南山近, 煙含北渚遙. 承恩威已醉, 戀賞未還鐿.

To where her villa looks out on green meadows singing simurghs descend from the Lavender Empyrean.

Yuan birds and egrets gather on long banquet mats, to immortal pipes phoenixes sing in harmony.

Close-by the trees touch on South Mountain, as afar mists enfold the northern isles.

Receiving Grace, all have grown drunk, craving enjoyments, we have not turned our horse-bits homeward.

Li Jiao here follows the well-established conventions of the court poem, whose rules of exposition permitted a range of variation known to all. In the opening couplet the title is amplified with a line on the villa and a line on the imperial visit; the second couplet describes the party, balancing the courtiers (yuan birds and egrets) with the imperial couple (phoenixes). The third couplet describes the scene symmetrically, balancing north and south, mountains and waters, proximity and distance; and the final couplet expresses gratitude and an enjoyment that makes the visitors reluctant to leave. Yet the courtier poets present were less effusive when visiting the politically unimportant Princess Changning than when visiting the powerful Princesses Taiping or Anle. At the estate of Princess Anle Li Jiao wrote as follows (03702): ${ }^{7}$

黄金瑞榜綘河隈，白玉仙興紫禁來. 碧樹青岑雲外聯，朱樓畫閣水中開. 龍舟下瞰鮫人室, 羽節高臨鳳女臺. 遽惜歡娛歌吹晚, 揮戈卻使曜露回.

ten 唯路, 㚙 here is understood as 宛鳥. In the last line I have followed Chuxue ji and Quan Tang $s h i$ in reading wei 未 rather than lai 來, the Wenyuan yinghua reading, which looks like an error.

${ }^{7}$ Wenyuan yinghua 176.4b sets this occasion with Princess Anle; the collection and Quan Tang shi make it Princess Taiping. In the fourth line Wenyuan yinghua reads qian 前 rather than zhong 中. In the last line I follow Wenyuan yinghua reading queshi 卻使 rather than gengque 更卻 of Quan Tang shi. There is a nice point in the first line of this poem, which I have translated as nominal, according to the received text. There is, indeed, a Scarlet River, Jianghe 綘河, as part of the stellar regions; hence it is an appropriate figure for the emperor coming from Heaven. However, in the antepenultimate position of the first line in the preceding poem we have the homophonous jiang 降, to "descend from." This is probably the correct reading; thus: "descends from the nook in the River [of Stars]." 
An auspicious placard of gold at a nook in the Scarlet River, then white jade coaches of gods from Lavender Precincts came. Sapphire trees, green pinnacles thrust up beyond the clouds, crimson mansions and painted towers appeared amid the waters.

His Dragon Boat spied downward into chambers of the merfolk, feathered insigniae look down on high from the phoenix girl's terrace.

Then in our pleasures came sudden regret that the singing and piping grew lateand a pike is flourished to enforce the Radiant Spirit to turn back. ${ }^{8}$

The formal pomp of these two poems by Li Jiao contrasts sharply with poems from another visit to Princess Changning's estate. This visit cannot be dated precisely, but it was probably in the early spring of 710, a month or two before the imperial visit described in the first piece above. The visitor was Shangguan Wan'er 上官婉兒, the most influential literary figure of the day, ghostwriter, it was said, for Zhongzong, the Empress, and the princesses. Shangguan Wan'er, the granddaughter of the court poet Shangguan Yi 上官儀, had as a child barely escaped death when her grandfather fell from power and her immediate family was executed. Her face tatooed with the mark of a criminal, she had been taken into the palace, where she rose through her talents to become Empress Wu's secretary. ${ }^{9}$ During Zhongzong's reign she became a political ally of Princess Anle and was made Zhonzong's "Consort of the Shining Countenance" (Zhaorong 昭容)一her tatoo having presumably been concealed by the makeup of a great court lady. She sponsored the foundation of the Xiuwen guan, organized the lavish poetry picnics for the amusement of the court, and served as arbitrix in poet-

\footnotetext{
${ }^{8}$ The reference here is to the Lord of Luyang waving his pike to make the sun turn back and thus protract time.

${ }^{9}$ Hou xi qi cai, zhi qing er bu sha ye 后惜其才, 止黥而不殺他. Xin Tang shu 76.3488.
} 
ry competitions. Shangguan Wan'er was every bit as capable of rhetorical formality as Li Jiao. But on the occasion of a private visit, she wrote "Twenty-five Poems on Visiting Princess Changning's Pool for Floating Winecups" 遊長寧工主流杯池二十五, which are rather different from the poetry composed in the august imperial presence (00272): ${ }^{10}$

檀樂竹影，風松聲. 不煩歌吹，自足娛情.

Swaying gracefully, bamboo shadows, whishing gusts, sounds of pines.

We need not bother with piping and song-

these serve to please my mood on their own.

The motif of natural sounds taking the place of manmade music was a commonplace of Nature poetry and can be traced back to Lu Ji's Zhao yin shi 招隱詩 in the third century. It takes a moment to recall that what Shangguan Wan'er is describing here is not wild nature but the Chengnan estate of an imperial princess. Or to put it more precisely, it is the estate of an imperial princess praised not in the glittering terms of court and immortal hierarchies, but as the dwelling of the recluse in the wilderness. As party music is replaced by natural sounds, so too is human companionship replaced by forests (00274).

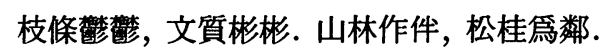

Boughs and branches, swollen and dense, pattern and matter in balanced perfection. My companions are the woods of the hills, pine and cassia are my neighbors.

Shangguan Wan'er finds one of the highest Confucian values, "pattern and matter in balanced perfection," in the trees, which thus may stand in place of human beings (the original locus of a balance between pattern and matter). If this poem had been written by someone outside the court, it might easily be read as an implicit rebuke to the literary amusements that Shangguan Wan'er herself organized for the court. In this "nature-ism" and in the "naive"

${ }^{10}$ The primary source of all these poems is Tangshi jishi 7. 
style appropriate to it, Shangguan Wan'er is anticipating Wang Wei's famous Wang-chuan $j i$ 輞川集. In the pentasyllabic quatrains she wrote on this same occasion, she comes closer still.

Before returning to Shangguan Wan'er's remarkable series of poems, which articulate the values of nature and the simple life within the highest echelons of court society, we might consider another series of poems that clearly reveals the uneasy conjunction of these two extremes. The "Nature" in which the earlier recluse was supposed to dwell was virtually defined by its figurative distance from the emperor and the center of power: so long as one was out of reach to the court and the bureaucracy, relative physical distance was immaterial. The recluse might consort with fishermen and woodcutters and still claim to be alone and away from all human society. ${ }^{11}$ The new "court recluses" of the Chang'an exurbs retained all the rhetoric of the traditional recluse. They claimed to inhabit a perfectly natural setting-although their version of " $\mathrm{Na}$ ture" was usually constructed at immense expense and labor-and they reveled in being cut off from all human society, which paradoxically made their dwellings a popular destination for visits by the emperor and his courtiers. Shen Quanqi's poem below offers a wonderful formulation: "Peach Blossom Spring meets the ninefold Palace." This was an encounter of antithetical extremes, in which the center of political power ("the ninefold palace") and the place defined by its rupture from centered political space (Peach Blossom Spring) came together.

On January 18, 710, His Majesty and the court paid a visit to the estate of Wei Sili 韋嗣立, a powerful figure during the reign of Empress Wu and one of the Senior Scholars in the Xiuwen guan. Wei Sili's estate was located in Parrot Valley in the foothills of Mount $\mathrm{Li}$, and the visit was made in transit between the capital and the winter palace on Mount Li. Wei Sili earned a good reputation among historians for his memorials urging fiscal restraint during this period of lavish expenditure; but on this occasion he was said to have provided a hundred wagons of food and rustic dinnerware for

11 Let me here dispose of the figure of "greater reclusion" dayin 大隱, the person who maintains a spiritual distance though serving in court. As popular a motif as that was, it does not figure importantly in these Tang poems. 
the imperial picnic. Zhongzong, delighted, renamed the place Xiaoyao Valley 逍遙谷, “the Valley of Free Roaming," and oxymoronically enfeoffed Wei Sili as the Duke Xiaoyao 逍遥公. ${ }^{12}$ To celebrate the occasion, Zhongzong and the literary courtiers all composed poems, which Wei Sili then had engraved on stone.$^{13}$ Zhang Yue 張説 wrote the preface, which is included in Zhang Yue's collected works as “An Account of the Eastern Mountain," Dongshan $j i$ 東 山記. ${ }^{14}$

The preface begins with an uneasy conjunction of the highest public office and a yearning for the private life in Nature:

The Minister of War and at the same time holding the lower third grade in the Secretariat-Chancellory, Grand Scholar in the Xiuwen guan, Lord Wei embodied in his person genuine tranquility, and his thoughts were in harmony with secluded remoteness. Though assisting gloriously in the halls of state, his concerns lie remote in woodland and heath. At the bend of the Eastern Mountain [i.e., Mount Li] he has an estate. There the mountain haze moves onto the moors, and mist in the thickets rises away from common things. Here are rocky tarns and bamboo slopes, a study among the pines and a plot for herbs. Rainbow springs shoot lightning, and cloudy trees moan emptily. All a blur, it seems like a dream; across difficult paths, one forgets all devices. He may be called a Kui or Long of hill and vale, or a Chaofu or Xu You in cap and robe.

In the final oxymoron, the legendary ministers of the ancient sageking Shun are made into recluses of the wilderness, while those who so resolutely fled public life, Chaofu and $\mathrm{Xu}$ You, are made to dress as officials. Some decades later, after describing a world of inverted values, $\mathrm{Li}$ Bai would return to this same example in the concluding section of the "Song of Minggao: to Cen the Summoned Scholar" 鳴香歌送岑徵君 (08084):

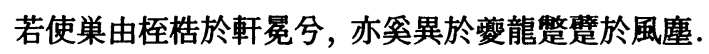

Were one to force Chaofu and $\mathrm{Xu}$ You

to be shackled by coach and crown,

12 There was precedent for this title, which had been granted to an earlier Wei, one Wei Xiong 韋夏 by the Northern Zhou emperor. In contrast to Wei Sili's double role, Wei Xiong was a recluse who at first refused to serve. I am indebted to David Knechtges for pointing this out.

13 Wenyuan yinghua $175.8 \mathrm{a}-11 \mathrm{~b}$. The poems survive in two series, one in pentasyllabic pailu and the other in heptasyllabic quatrains.

${ }^{14}$ Quan Tang wen 226.1a-2a. 
how would that be different from Kui and Long limping along in the windblown dust?

Li Bai finds in these figures a nightmare of human nature violated by inappropriate roles; Zhang Yue, however, cheerfully celebrates the coexistence of antithetical impulses. It was precisely such doubleness that made possible the nature poetry of exurban Chang'an and Luoyang. Praise required historical examples, and there were none in the writers' vast repertoire of cases that perfectly fit the oxymoronic union of statesman and recluse. The closest anyone could come was the Eastern Jin statesman Xie An 謝安, to whom Zhang Yue refers in his preface and whose example is implicit in its title. Xie An did have a villa in exurban Jinling, where he entertained courtiers, but he hardly fit the description of a Nature-loving recluse. Whenever "Peach Blossom Spring touches the ninefold Palace," the proper result is either that $\mathrm{Xu}$ You washes out his ears and runs away or the emperor drafts a useful minister into his service. The poets, hard-pressed for historical examples with which to praise Wei Sili, had to turn to those recluses about to lose their amateur status, such as Zhuge Liang and Taigong. The following is Shen Quanqi's 沈佺期 contribution to the occasion (05070): ${ }^{15}$

\section{奉和幸韋 嗣立山莊侍宴應制}

台階好赤松, 別業對青峰. 茅室承三顧, 花源接九重.

龍旗榮秀木, 鳳輦拂疏筑. 徑狹千官擁, 流長萬騎容.

水堂開禹膳, 山閣獻堯鍾. 皇鍳清居遠, 天文謇獎濃.

䉷泉他夕夢, 漁釣往年逢. 共榮丞相府, 偏降逸人封.

A Companion Piece to Imperial Command: “His Majesty Visits Wei Sili's Mountain Estate-in attendance at a banquet"

His terrace stairs are right for red pine, ${ }^{16}$ his country villa faces green peaks.

Thatched chambers thrice received royal regard, ${ }^{17}$

${ }^{15}$ The primary anthology sources are Wenyuan yinghua $175.8 \mathrm{~b}-9 \mathrm{a}$ and Tangshi jishi 11.160 . These present some variants from the present text followed, which is that of Lianbo 連波 and Zha Hongde 查洪德, Shen Quanqi shiji jiaozhu 沈佺期詩集校注 (Zhengzhou: Zhongzhou guji chubanshe, 1991), p. 116.

${ }^{16}$ Although this probably refers here to the legendary tree, the association is clearly the Master Red Pine, Chisongzi, an immortal commonly referred to in estate poems of the period.

${ }^{17}$ Referring to the three visits Liu Bei payed to gain the cooperation of Zhuge Liang. 
Peach Blossom Spring touches the ninefold Palace.

Dragon banners wind through tall trees, phoenix palanquins brush sparse bamboo.

The paths strait, the thousand officers crowd, the stream long, room for ten thousand riders.

At the hall by waters appear viands for $\mathrm{Yu}$, in a mountain tower Yao's goblets are offered.

Our Sovereign examines this pure, remote dwelling, celestial text is a rich sublime reward.

Cliff streams are dreams of evenings to come;

fishing was encountered in years gone by. ${ }^{18}$

We share the glory of the Minister's Precincts,

he is specially granted enfeoffment as one disengaged.

In the last couplet, as a special mark of imperial favor, Wei Sili is publicly honored with a title that by its definition is beyond the emperor's power to bestow, a title that declares indifference to the public glory it represents.

Any student of the Tang knows that the Tang elite could enjoy oxymorons and contradictory values poetically, free from any sense of conflict. I strongly suspect that Wei Sili did not wake up in the night and worry whether he wanted to be a leading officer of the court or live the private life in his exurban estate. He obviously enjoyed both roles and, moreover, enjoyed displaying himself to the court as the private man living in Nature. But playing such a double role depended on the development of Chengnan and the capital region as "domestic" Nature, a space that was accessible to court and capital and could "stand for" more remote regions of reclusion.

The "distance" of Wei Sili's estate (line 11) is spiritual; the need for more pragmatic distances of reclusion is often proposed as something to be rejected. One of the most durable commonplaces in the poetry of this brief period took the form: Why bother to go far away to X [dwellings of the immortals or famous sites of wild Nature]?you can find it right here! Or as Shangguan Wan'er observed epigrammatically (00276):

${ }^{18}$ Probably an allusion to Taigong. 
莫論圓嶠, 休説方壶. 何如魯館, 即是仙都.

Tell me no more of Round Spire, stop talking of Fanghu.

How can they match the lodge of $\mathrm{Lu}-{ }^{19}$

the Great City of Immortals is right here.

Nearby in the Chengnan region the aristocrats and courtiers of the early eighth century found the land of immortals and the great mountains of hermits. This was Nature purchased (or confiscated) and physically modeled. Something of the dominance attained by this domestic version of Nature can be seen a century later, when the famous writer Liu Zongyuan 柳宗元 was exiled to the remote region of Yongzhou, the realm of wild Nature. There he purchased a small and useless hill, Gumu Hill, cleared its excessive vegetation to reproduce the aesthetic of exurban Chengnan, an aesthetic based on constructed Nature; and then he speculated on how much people would pay for it if it were located in the capital region. ${ }^{20}$

The estates of Chengnan and farther reaches of the capital region, such as Wei Sili's estate by Mount $\mathrm{Li}$, gave private life a practical space within a public life. One did not need to shrink away into diminutive spaces of imaginary vastness, as had Yu Xin 㣎信 (513-581) in the "Poetic Exposition on My Small Garden," Xiaoyuan $f u$ 小園賦; nor did one need to remove oneself from public life altogether. The aristocrat and the court official had discovered the weekend retreat. Sometimes they acknowledged the contradiction of the public man in Nature, as at the end of the passage by Zhang Yue above; but more often, once they set out from the city, they were content to ignore it and lose themselves in the role of the recluse. Reclusion became not an absolute decision but one role among many, a construct that included both the constructed Nature of the Chengnan estate and the construction of private life through poetry.

Some of the finest examples of the estate poem are Du Shenyan's “Five Companion Pieces for Wei Chengqing's 'Visiting the Moun-

19 The “Lodge of Lu," Lu guan 魯館, is elsewhere referred to in court poetry of this period. I am uncertain of the allusion, if it is such. It might simply be a building on the estate.

${ }^{20}$ Liu Zongyuan ji 柳宗元集 (Beijing: Zhonghua shuju, 1979), pp. 765-66. 
tain Pool of Princess Yiyang'” 和韋承慶過 義陽公主山池五首 (0374145), probably from Zhongzong's second reign (Du Shenyan died in 708). ${ }^{21}$ Wei Chengqing was the half-brother of Wei Sili and had been a close associate of the infamous Zhang Yizhi. The Princess Yiyang was the daughter of Gaozong's Pure Consort Xiao, killed by Empress Wu, and had been out of favor during Empress Wu's reign.

The set begins with an announcement of the impetus for the visit: yexing, a "rustic impulse," the mood of the moment. The picnickers leave the capital, carefully affirming their commitment to official life while at the same time admitting their urge to enjoy the "wilds" of Chengnan.

1

野興城中發, 朝英物外求. 情懸朱䋐望, 契動赤松游.

海燕巢書閣, 山雞舞畫樓. 雨餘清晚夏, 共坐北䈆幽.

A rustic impulse came forth in the city, the flower of court sought the intangible.

Hopes for vermilion cords clung in their hearts, ${ }^{22}$ but their fancies urged red pine excursions. ${ }^{23}$

Sea swallows nest in the library tower, pheasants dance in the painted mansion.

The last of the rain cools late summer, as we sit together in North Cliff's seclusion.

俓轉危峰逼, 橋斜缺岸妨. 玉泉移酒味, 石簿換粳香. 綰霧青條弱, 牽風紫蔓長. 猶言宴樂少, 別向後池塘.

The path bends round, sheer peaks press on it, the bridge slants where the gaping bank blocks. ${ }^{24}$

${ }^{21}$ See Xu Dingxiang 徐定祥, Du Shenyan shi zhu 杜審言詩注 (Shanghai: Shanghai guji chubanshe, n.d.), pp. 10-11. The primary anthology sources are Wenyuan yinghua $165.7 \mathrm{~b}-8 \mathrm{a}$ and Tangshi jishi 6.77-78. I have followed Du's text except where indicated.

${ }^{22}$ Vermilion cords mark high office.

23 "Red Pine" is the Tangshi jishi reading, referring either to the "red pines" or to the immortal Red Pine. Wenyuan yinghua reads “Red Spring," chiquan 赤泉, an immortal place.

${ }^{24}$ Reading xie with Tangshi jishi; other texts read hui 回, “turn," wei 危, “sheer," and tong 通, “gets through." 
Jade springs displace the flavors of wine, stone marrow replaces aromas of rice. Threading through fog, the green twigs supple, ${ }^{25}$ pulling the breeze, lavender vines long.

As if to suggest that the joy of the feast is diminished, we go off elsewhere, to the pond at the rear.

攜琴遶碧沙, 搖筆弄青霞. 杜若幽庭草, 芙蓉曲沼花. 宴遊成野客, 形勝得山家. 往往留仙歩, 登攀日易斜.

Holding zithers, we round sapphire sands, waving brushes, we toy in green wisps of cloud. Duruo's the plant of this secluded yard, lotus, the flowers of the winding pond. As we picnic we become travelers of the wilds, in scenic splendor we reach a home in the hills. Everywhere the paces of immortals are stayed, we climb our way up, and the sun soon slants down.

4

攢石當軒倚，懸泉度牌飛。鹿琵衝妓席，鶴子曳童衣. 園果嘗難遍，池蓮摘未稀. 卷策唯待月，應在醉中歸.

Clustered stones rest against railings, waterfalls fly past the windows.

Dwarf deer dash upon mats for dancers, little cranes tug at the gowns of the lads. We cannot taste all the fruits of the orchard, pool lotuses are picked but not made few. We roll up curtains to wait for the moon, we will surely go home in drunkenness.

5

賞玩期他日, 高深愛此時. 池爲八水背, 峰作九山疑. 地靜魚偏逸, 人閒鳥欲欺. 淸溪留別興, 更與白雲期.

${ }^{25}$ Reading tiao with Wenyuan yinghua and Tangshi jishi rather than si 絲. 
For amusements we plan on days to come, for height and withdrawal we cling to this moment.

This pool turns away from the Eight Rivers, ${ }^{26}$ the peaks make us wonder if they be the Nine Mounts.

The place serene, fish particularly insouciant, the humans at ease, birds make sport of us.

At Blue Creek, the impulse to stay our departure, we agree to meet again in the white clouds.

It scarcely matters that this was the estate of an imperial princess. She was a middle-aged princess of no particular political importance; we suspect she must not have been in residence, or some polite acknowledgment of her existence would have been required. Her estate had become essentially a rustic park for the amusement of Chang'an officials.

"Rustic impulses" could be satisfied by a good daytrip to Chengnan and, even more important, by the promise to repeat the experience. Such anticipation of repeating the experience was a favorite ending for the party poem during this period, but this particular party involves playing the recluse in the wilderness. Repeatability distinguishes a temporary role from an absolute choice about how to live one's life.

When the court meets Nature, and the ninefold Palace touches Peach Blossom Spring, there are other encounters. In the poems above and other estate poems there is a particular attention to junctures where something of Nature meets something artefactual and human. The poets are drawn to such margins where something of Nature leans on, presses against, bounces off, or tugs at the human presence. Active verbs in the "eye" of the line bear special weight. The architecture is not simply "in" the landscape: it is construed in an active relation-bending, avoiding, touching its natural surroundings.

Such active conjunctions are stylistic as well as thematic and descriptive. Nature is recast in a transformation of the formal court style, in couplets associated with the artificial craft of the court poet.

${ }^{26}$ The Eight Rivers are those of the Chang'an region. Reading wei with Wenyuan yinghua and Tangshi jishi, rather than fen 分. 
There is none of the stiffness demanded by the imperial presence, but in this "touching" or "meeting" ( $j i e$ 接) of antithetical worlds Nature is often figured anthropomorphically, or at least, as acting with intention. Poets openly "construct" Nature just as estate builders do; and their pleasure is not in wildness but in the play of Nature's partial humanization.

The encounter is transitory. The temporary quality of the excursion is always on the poet's mind. Through the last three poems of the series Du Shenyan notes the day passing, thinks of leaving, and anticipates returning.

Du Shenyan's series represents the legacy of the banquet poem. It sustains the tension between art and Nature, with the poet always ready to reluctantly withdraw. Visiting the estate of Princess Changning in 710, Shangguan Wan'er crosses the boundary of forgetting; she writes "as if" she truly were the recluse who belonged in the natural setting, and her style shifts accordingly. Later in 710, after Zhongzong's death, Shangguan Wan'er was executed. But this woman who set court poetic fashion seems to have been announcing a new sensibility in this, the last year of her life. It was a sensibility that had profound implications for the breakup of an aristocratic world. The mobility of roles embodied in the "weekend recluse" was the counterpart of a greater mobility of status and position. If the imperial Consort of the Shining Countenance, whose face was tatooed as a criminal, could play the male hermit, then roles were not determined by one's status or by the social situation: they could be freely chosen, chosen in such a way that allowed the person to forget her other life. That element of self-fashioning in role-playing was to be one of the strongest characteristics of the period that followed, the High Tang.

Shangguan Wan'er's series of twenty-five poems on Princess Changning's estate is, in many ways, a hybrid work. In the first of the pentasyllabic regulated verses the line, "The jade ring springs up over the remote construct”' (yuhuan teng yuan zhuang 玉環騰遠創), recalls the figured formality of imperial visits. ${ }^{27}$ But in the process

${ }^{27}$ The six pentasyllabic regulated verses are found in Wenyuan yinghua 176.8a-9a. While these do not constitute a clear temporal progression, as does Du Shenyan's set, the first seems clearly an introductory piece. These, along with other poems of the set, are included in Tangshi jishi, where they are arranged by genre. In addition to the pentasyllabic regulated 
the Consort of the Shining Countenance, one of the most powerful political and cultural figures of her day, is transformed into the recluse who shuns the world, describing herself in most unladylike terms as "wild and free" (fangkuang) (00281):

放曠出煙雲，蕭條自不群. 濑流清意府，隱几避翼氛.

石畫裝苔色, 風棇織水文. 山室何爲貴, 唯餘蘭桂薰.

Wild and free, I emerged from mist and cloud, with cool indifference I felt not of the common herd.

Rinsing in currents, I cleared the seat of thoughts, leaning on an armrest, I shunned the noisy pall. Rock paintings adorned in the colors of moss, the wind's shuttle weaves patterns in waters. ${ }^{28}$

What makes these mountain chambers so prized?here remains the aroma of orchid and cassia.

The first half of this poem is strongly marked as a male role. The transformation of reclusion from an absolute decision about how to live or a temporary consolation during one phase of a person's life into weekend role-playing made it possible to assume the role with greater ease than had heretofore been possible. During this period dominated by women (as opposed to the reign of Empress Wu, which was dominated by one woman), Shangguan Wan'er could unselfconsciously step into a role that had previously been reserved for men. In none of the twenty-five poems is there even a hint that the author is a woman; they do not express any of the unease women writers sometimes showed in transgressing their gender roles. In the mixed-sex court occasions of Empress Wu's and Zhongzong's reigns we might expect that gender would disappear into status, but in these poems Shangguan Wan'er assumes a private role, ostensibly speaking for herself.

Just how literally are we to read the recluse's gesture at the beginning of the third of the pentasyllabic regulated verses (00279)?

霞曉氣清和，披襟賞薜蘿.

verses, there are seven tetrasyllabic quatrains, nine pentasyllabic quatrains, and three heptasyllabic quatrains.

${ }^{28}$ Tangshi jishi, the primary source, reads $m u$ 木 for shui 水. Although shui is by far the easier reading, $m u$ is an interesting possibility. 
Morning of clear skies, air gentle and cool,

I pull open the folds of my gown to enjoy the ivy.

Pijin 披襟, “pulling open the folds of one's gown," also means to "feel open and free"; but in the Tang the psychological implications can never be entirely dissociated from the empirical act that embodied them. We have difficulty imagining the middle-aged Consort of the Shining Countenance wandering alone through the mountains, and even more difficulty imagining her baring her breast in a gesture of insouciant freedom. Perhaps a discreet tug would have been enough to convey the message visually-if that were necessary-a mere sign of the hermit's liberation from sumptuary propriety. But just as Wei Sili, Minister of War and Grand Scholar of the Xiuwen guan, can play at being a hermit, so can Shangguan Wan'er.

Shangguan Wan'er's pentasyllabic quatrains in this series have a staged simplicity that in some ways anticipates Wang Wei's Wangchuan ji.

攀藤招逸客, 侒桂協幽情. 水中看樹影, 風裏聽松聲.

Pulling myself along by vines, I summon the aloof one, lying resting against cassia suits my reclusive mood.

In the waters I look at reflections of trees, in the wind I listen to sounds of the pines. ${ }^{29}$

泉石多仙趣，撖餐寫奇形. 欲知堪悦耳，唯聽水泠泠.

Springs and rocks offer much zest of immortals, ravine and cliff outline wondrous shapes.

If you would know what most delights the ear, just listen to the trickling of waters. ${ }^{30}$

澱壑恣登臨, 塋目復怡心. 風簧類長笛, 流水當鳴琴.

Climb cliff and ravine as much as you please, they dazzle the eye and content the heart.

Breeze in bamboo is like long flutes,

${ }^{29} 00283$. Despite the simplicity of the diction, the use of a parallel second couplet in a quatrain recalls late Six Dynasties practice.

3000285 . 
flowing waters serve as the sounding zither. ${ }^{31}$

瀑溜晴疑雨, 叢簧書似昏. 山中畺可玩, 暫請報王孫.

Cascading streamlets seem rain in clear skies, bamboo thickets in daylight seem dusk.

One may truly amuse oneself in the hills, and I pray you let me report this to the Prince. ${ }^{32}$

The buildings of Princess Changning's estate are hardly ever mentioned, except in the concluding couplets of the first of the regulated verses (00277).

錅山便作室，憑樹即爲楹. 公輸與班爾，從此遂傽聲.

Digging in hills, she made her chambers, laying weight on trees, she formed pillars right there.

Gongshu Ban, Lu Ban, and Wang Er $^{33}$

from this henceforward sheathe your renown. ${ }^{34}$

The venerable trope of Nature taking the place of human artifice, from the Zhao yin shi of Lu Ji 陸機 and Zuo Si 左思, seems to have been made literal on Princess Changning's estate. If the estate actually used artificial grottoes or rooted trees (still living?) as architectural supports, it would be an excellent index of a naturalizing fashion at work in the construction..$^{35}$

Shangguan Wan'er's series is a stylistic hybrid, at times seeking a language proper to the experience of Nature, at other times, as when she rhetorically addresses the exemplars of artifice, coming

3100286 .

32 00289. The "Prince," wangsun 王孫, is a emblematic figure from “Calling Back the Recluse," Zhao yinshi 招隱士, in the Chuci. There the recluse who lives in dangerous and violent nature is recalled to civilization. Shangguan Wan'er's inversion anticipates the closing couplet of Wang Wei's famous “Autumn Darkness Dwelling in the Mountains," Shanju qiuming 山居秋暝: “Spring's sweetness ends as it will, / yet you, my Prince, may linger on” 隨意 春芳歇, 王孫自可留.

${ }^{33}$ Gongshu Ban and Lu Ban were two famous craftsmen of antiquity, who in some traditions are collapsed into a single name. Wang Er is another famous craftsman. I am indebted to David Knechtges for the identification of Wang Er.

${ }^{34}$ Taking the peculiar compound taosheng in the sense of taoguang 塪光.

35 One possibility is that naturalizing architecture has priority here and that Shangguan Wan'er is adapting her poetic style to correspond to it. 
up with phrases such as taosheng, "sheathe renown." But in these poems we can see the beginning of a sensibility for stylish rusticity in the highest levels of capital society. This forms the background for one of the most common dimensions of High Tang poetry, when the gentry of the capital would take a day off and venture into Chengnan to "visit the recluse" or themselves retire to their estates to await such visits.

It is but a short step from Shangguan Wan'er visiting Princess Changning's estate to the poetry of the private estate. Song Zhiwen 宋之問 had an exurban Luoyang estate at Luhun and a Chang'an estate at Lantian, an estate that would, in the next generation, become Wang Wei's own.

My Mountain Estate at Lantian 藍田山莊 $(03253)^{36}$

宦遊非吏隱，心事好幽偏. 考室先依地，爲農且用天.

輞川朝伐木, 藍水暮澆田. 獨與秦山老，相歡春酒前.

Official travels are not reclusion in low office, the heart loves being hidden and out of the way.

To site your house, give precedence to following the lay of the land;

to be a farmer, make use of Nature.

At Wang Stream I cut down trees at dawn, with the Lan's waters I irrigate fields at dusk.

Alone with old men of the hills of Qin

I make merry before the spring wine.

As Wei Sili, by the title of Duke Xiaoyao, was figured as Zhuang$z i$, the Clerk of the Lacquer Garden, who attained spiritual freedom in his low post, so Song Zhiwen claims the status of liyin 吏隱, "reclusion in low office," "reclusion as a clerk." Although by no means a great court officer of Wei Sili's stature, Song Zhiwen, one of the Regular Scholars (zhixueshi 直學士) of the Xiuwen guan and a courtier in close attendance on Zhongzong, could hardly claim "reclusion in low office." It was, however, a pleasing role; and the poetry of this role was taking shape around the private estate.$^{37}$ Like

\footnotetext{
36 Wenyuan yinghua $319.7 \mathrm{a}$. This juan contains some interesting seventh century precedents by Yang Jiong and Lu Zhaolin.

37 See also 03185, 03190, and 03252. Song also had an exurban Luoyang estate at Luhun.
} 
Princess Yiyang's estate, which in Du Shenyan's poems bends to the topography, and Princess Changning's estate, where trees serve as columns, Song Zhiwen's buildings "follow the lay of the land": the artefactual is made to conform to the natural.

In the decades that followed the stylized simplicity of the great courtier who "follows the lay of the land" and plays the farmer or recluse became commonplace. The more elegant courtly verse, however, did not disappear altogether. Imperial presence anywhere summoned a formality that remained by and large unchanged from Zhongzong's reign and earlier. And though the grand might prefer to assume the pose of the simple life, there were feasts and other occasions that demanded echoes of imperial formality. Du Shenyan's "artful" style of estate poetry, which foregrounds the margin between Nature and art, did not disappear; it survived and was transformed, creating an image of nature different from the one preferred by the courtier turned weekend recluse.

One remarkable couplet from Du Shenyan's series reads:

Dwarf deer dash upon mats for dancers, little cranes tug at the gowns of the lads.

This couplet was remembered in an early poem by Du Shenyan's grandson $\mathrm{Du} \mathrm{Fu}$, already a mature man and writing in the 740 s or early 750 s.

Another Upon Zheng's Eastern Pavilion (10908)

華亭入翠微, 秋日亂清輝. 崩石攲山樹, 清涷电水衣.

紫鱗衝岸躍, 蒼隼護巢歸. 向晚尋征路, 殘雲傍馬飛.

This splendid pavilion enters azure mists, where comes autumn sun's clear glow in disarray.

Fallen boulders slant upon mountain trees, and clear ripples tug sheets of algae.

Lavender scales vault, dashing on shores, a blue-gray hawk returns to guard the nest. Towards evening I seek the road I must travel, with tattered clouds flying past horse's flank.

Echoing Grandfather's memorable "tug"' ( $y i$ 电) in the third position of the pentasyllabic line, Du Fu cannot resist adding the 
parallel “dash on" (chong 衝) across the couplet break.

Whoever the Zheng of Du Fu's poem was, his or her immediate family would not have been in office; that would usually have required some designation of official title when stating the occasion. We have left both court and officialdom; and yet the place is depicted with distinct craft of an older court poetry. As the aristocrat and high court officer learned to play the role of the recluse, with a poetry of simple grace appropriate to the role, a poet with no office could play the gracious courtier when visiting the pavilion of someone of no rank.

The same style occurs elsewhere in Du Fu's earlier poetry, most notably in the two series comprising fifteen poeem on visiting the "'mountain woods" of one General $\mathrm{He}(10936-45,10946-50)$. And $\mathrm{Du} \mathrm{Fu}$ would frequently allude to that style in his later poetry, whenever he wanted to evoke the magic of a lost era.

To assume a temporary role does not mean one is insincere, but simply that a life decision is not required. Wang Wei's poems often celebrated the pleasures of the private life in nature at Wang's Lantian estate, and scholars have often placed these poems in the context of a withdrawal from active participation in court life. Such an attempt to link the values expressed in poetry to the putative sentiments of an extended phase of a person's life can be misleading. One could be both recluse and courtier, without being tormented by the contradiction (or the contradiction could be transformed into a theme that was part of the whole). Very gradually through the eighth century the "private" came to be conceived not as the alternative to a public life, but as part of a life that could simultaneously contain both public and private.

Opening a space for the private or for a theatrical performance of the private within the social sphere was an important event in Chinese civilization, and over the next few centuries a cultural repertoire of private roles for public people evolved. Although ownership did not become an important theme in prose and poetry until the ninth century, it was what separated the estate poem from a simple excursion into Nature. The Six Dynasties recluse had usually lived in unowned Nature; increasingly in the Tang, the peace and security found in natural surroundings required ownership of 
space. ${ }^{38}$ Ownership and construction go hand in hand: no one digs ponds, builds hills and pavilions, or plants groves in wild, unowned Nature. Shelter, and not the simulacrum of Nature, is the recluse's construct. But for the weekend recluse on his estate, the role of recluse is assumed and the space is constructed: experience is staged, and the person having the experience will ever more loudly claim his spontaneity and insouciant ease.

Since the rounded contours of hills, flowers, and trees were commonly figured as parts of women, we might think of Shangguan Wan'er, her face tatooed with the mark (wen 文) of a criminal, named at the same time The Shining Countenance, Zhaorong. She was inclined to write, literally, on Princess Changning's natural landscape (00282):

莫怪人題樹，祇爲賞幽棲.

Don't blame me if I write upon your treeit's only because I appreciate this hidden roost.

Nature is both the topic and the material medium of expression; expression declares Nature to be such. But Nature here is a socially framed space designed to elicit such an expression, and the expression is reinscribed on Nature to be displayed to the human entourage. If there remains any trace of unease in the contradiction, it is in mo guai 莫怪, “don't blame me," or "do not think this [improperly] strange." " This gracious injunction calls to mind the propriety of Nature uninscribed, unmarked by either appreciation or blame.

${ }^{38}$ Xie Lingyun, of course, wrote of his estate; but it was as a space of radical separation from public life rather than a weekend retreat. By the early ninth century writers commonly speak of ownership explicitly, along with purchase and prices.

${ }^{39}$ It is uncertain here whether guai 怪 should be taken simply as "marvel," or in the extended sense it had already acquired of "blame". 